industry, offering them the opportunity to become acquainted with each other, to consider the progress of our science, to discuss their professional interests, to establish business relations, to manage affairs. The welcome accorded our beginnings has gone to prove that our idea met a real need. You will find here the scholar, the professor from our large colleges, chemical institutes, and national institutions; here you will meet the manufacturers, the representative of our big syndicates; you will find the engineer and the financier who devotes his energy to the marketing of the products of our industry; more particularly you will find the chemist, from the Doctor of Science and the graduate of our colleges to the man taught simply by experience in the laboratory; all of these in my voice bid you welcome to-day.

The Cercle de la Chimie counts itself happy that you, Colonel, and your distinguished collaborators show yourselves ready to accept our hospitality, which though modest is none the less cordial. The presence on the table in our reading room of American journals will prove to you the interest which those who frequent our club take in following the progress of your science and industry. Are they not sure to find in reading these evidences of the keen thought, daring initiative, and talent for organization which are the characteristics of your national spirit?

Is it rash to hope that the reception we have given you this evening may be the beginning between American and French chemists, of continuing friendly relations whereof we know so well how to estimate the worth? It is to the development of these relations, to their contribution to the approaching victory of the allied armies which we all are preparing for in our factories and laboratories that we now invite you, Colonel, to drink of the wine of France.

\title{
WILLARD GIBBS MEDAL AWARD
}

The Willard Gibbs Medal for I9I8 was conferred on William M. Burton, Ph.D., in recognition of his distinguished work in petroleum chemistry, at the meeting of the Chicago Section of the American Chemical Society held at the City Club of Chicago, May 17, 19I8. Introductory remarks by L. M. Tolman, chairman of the Section, were followed by an aptly phrased presentation of the medal by Dr. Ira Remsen, in which he paid pleasing tribute to his former student. Dr. Burton's address of acceptance and the remarks of Mr. Tolman are printed herewith.

A reception and dinner preceded the meeting at which informal addresses were made by Lucius Peter, president of the Chicago Association of Commerce; Thomas F. Holgate, president of Northwestern University; George N. Carman; president of Lewis Institute; W. E. Stone, president of Purdue University; Julius Stieglitz, director of the Department of Chemistry, University of Chicago.-EDrrok.

\section{INTRODUCTORY ADDRESS}

\section{By L. M. Tolman}

In $1909 \mathrm{Mr}$. William Converse, at that time chairman of the Chicago Section, had the idea that it would be a good thing to found a medal which should be given as a reward for work in chemistry, and he provided the funds to found the Willard Gibbs Medal.

The first thought was to make it local in character but it was soon decided that it should not have restrictions of any character put upon it. It was provided in the rules for the award of this medal that a jury of twelve eminent chemists, by their vote, could award this medal to any person who, because of his eminent work in or original contributions to pure or applied chemistry, was deemed worthy of such an award. It was not, therefore, limited to chemists of this country, but the jury was given an open field to choose the one they should consider most worthy to honor and, as you will recollect, the first chemist to whom the award was made was Arrhenius, the famous Swedish chemist.

The jury as it is made up at the present time is representative of the American Chemical Society. At one time, it was provided by the rules that at least half of the members of the jury should be from the Chicago Section, but as that seemed to have too much of a local suggestion, it was decided that this restriction on the jurors should be removed and the only restriction now is that of the four jurors elected each year, not more than one shall be from the same Section of the American Chemical Society. As one reads over the present list of jurors and those that have served on the jury in the past, he finds a list of men composed of the most prominent chemists in this country. "Out of the twenty-eight names who have served as jurors since the establishment of the medal, we find the names of ten past-presidents of the American Chemical Society, and of the present jury of twelve, we find that five have been presidents of the American Chemical Society. Certainly, it is an honor to have such a body of men give one a vote of confidence.

What is a medal? Generally, a little piece of metal with an inscription upon it: sometimes made of gold, sometimes of silver, and sometimes of iron or copper; but the value of the metal has little to do with the significance or value of the medal. It is what it signifies, what it represents, and who awards it that gives it its value, and as one looks back over the past seven years of the award of this medal, its founder must feel satisfied and the recipients of the medal, proud and honored.

Chemistry is to-day playing a very conspicuous part in the history of the world. A few meetings ago, we heard from Major Auld, of the British Commission, of the advanced organic chemistry that is playing such an important part in the matter of gas attacks and gas defense. We know of many other fields where chemistry in this time of war is taking a most important and conspicuous position, and doubtless many of the chemists now at the front will receive medals of honor for bravery in time of peril and for discoveries of importance, which may be of service; but none, I believe, of these discoveries, while perhaps more spectacular, will be of greater importance to their country or more necessary in carrying out this war than the discoveries of our medalist of this evening. If we look over the various activities of the war, we must realize what a tremendous factor gasoline is playing in this great struggle, and that we, and our allies as well, would be at a tremendous disadvantage, if there should be a shortage of supplies. Had it not been for the processes and discoveries of $\mathrm{Mr}$. Burton and his associates, we might be facing that particular condition at this time. We have but to think of aeroplanes, automobiles, and submarines to realize the effect of a shortage of gasoline at this time.

As I look back again over the illustrious names of the men to whom this medal has been awarded, and over the names of the jurymen who have served in bringing about this award, I know of nothing that I would consider of greater value or honor than to have been voted, under the broad terms of the rules of this award, the honor of receiving the Willard Gibbs Medal 
I am sure that Mr. Burton feels as I do-that it is a reward, a recognition, paying in part for some of the struggles and disappointments which preceded the final success of his work.

Chicago, IIIINOIS

\section{MEDAL ADDRESS}

\section{CHEMISTRY IN THE PETROLEUM INDUSTRY}

By WILLIAM M. BÜRTON

Four years ago we assembled to witness the awarding of the Willard Gibbs Medal to Dr. Ira Remsen, of Johns Hopkins University, and one year ago we met for the same purpose in the case of Prof. Edward W. Morley, of Western Reserve University. Both of these gentlemen were honored preceptors of mine, and it was indeed a great pleasure to me to be present on those occasions. I never thought, however, that I would ever be the fortunate recipient of the Willard Gibbs Medal, but the unexpected and improbable very often occurs, and it is so in my case. I, therefore, hasten to extend to the Chicago Section of the American Chemical Society my deepest appreciation of the honor it has conferred upon me.

This event reminds me of a most prominent feature in Dr. Remsen's course of instruction, namely, that the best preparation for a career in technical chemistry is thorough training in the pure science, anci I was equally impressed with the introductory sentence of Dr. Morley's address last year, when he said "The best incentive for research work is the work itself." Both of these great teachers have exemplified these principles most happily in their professional careers, and I trust you will find my remarks thoroughly imbued with the influence of their invaluable instruction.

In considering the part that chemistry has played in the petroleum industry, it might not be unwise to review, briefly, the early history of the industry in this country. You have all heard of the first oil well, drilled by Col. E. L. Drake, near Titusville, Pa., in I859. Prior to that time petroleum was found in small quantities floating on the surface of springs or small streams of water in western Pennsylvania, and this oil was claimed by the Indians to have marvelous curative properties in the treatment of every manner of disease. The white man, with true commercial instinct, sold the oil in bottles as a general cure-all. The demand for the oil exceeded the supply, and Colonel Drake conceived the idea that if the oil came to the surface of the springs and rivers, there must be large quantities of it in the underlying strata of the earth. He, therefore, with the most primitive machinery, drilled a well near Oil Creek, in western Pennsylvania, and before he had proceeded Ioo feet into the ground the oil appeared in such large volume that it was difficult to take care of it.

At that time there was great need for a cheap and convenient illuminating material to supplant the expensive animal and vegetable oils which were used for that purpose. Samples of the petroleum prior to Colonel Drake's discovery were sent to Professor Silliman, of Yale College, who distilled the oil and made separations according to the boiling points of the various fractions. In his report he stated that portions of these distillates might well be utilized for illuminating purposes.

The promoters of the oil business acted upon Professor Silliman's suggestions, and this was the inception of the petroleum refining industry in this country.

For a great many years after Prof. Silliman's investigation, chemistry played a very small part in the practical workings of the refining of petroleum. The refiner learned to treat the illuminating oil distillate with strong sulfuric acid and alkalies, which improved the character of it somewhat, but the methods of refining were crude and wasteful. The only portions of the petroleum which were used at first comprised the fractions boiling between $100^{\circ}$ and $300^{\circ}$. C., which constituted somewhat over 50 per cent of the total mass of the crude oil. The lowboiling fractions which we now comprise in the generic term of "naphthas" were thrown away, as were also the high-boiling residues, called "tar." The tar, however, was soon utilized for preparing lubricating oils of very indifferent quality. It was not until about 1870 , when M. I. Hull, of Cleveland, Ohio, first devised the so-called "vapor stove," that the naphtha fractions of the oil were utilized. But even then the uses for the naphtha fractions did not cause a demand equal to the supply, and tnuch of the naphtha was wasted, a common practice being to throw it into the creeks and rivers, where it evaporated. Millions of gallons of this material, now indispensable for automobiles, were thus lost.

These conditions continued until $188_{5}$. Up to this time practically the sole source of petroleum in America was western Pennsylvania. But in 1885 , or 26 , petroleum was found in western and northwestern Ohio, near the town of Lima, and the fact that this oil contained from one-half to one per cent of sulfur attracted immediate attention. The ordinary refining methods of distillation and treatment with sulfuric acid and alkali were found to be totally inadequate to secure refined illuminating oils of suitable quality. Therefore, the industry turned to the chemist to solve the problem of extracting the sulfur, and producing satisfactory products. 